\title{
Cultivar mixtures as part of integrated protection of spring barley
}

\author{
Anna Tratwal ${ }^{1} \cdot$ Jan Bocianowski ${ }^{2}$ \\ Received: 28 September 2016/Accepted: 21 November 2017/Published online: 11 December 2017 \\ (C) The Author(s) 2017. This article is an open access publication
}

\begin{abstract}
Barley powdery mildew is caused by the fungus Blumeria graminis f. sp. Hordei. Monoculture and the use of diseaseresistant varieties on large-scale usually lead to the selection of new pathogen races able to overcome the resistance. The use of variety mixtures can significantly improve the control of the disease and provides stable yield among different environments. To assess the effects of the variety mixtures of spring barley on the intensity of powdery mildew infection, we conducted field trials during four growing seasons at two locations contrasting in soil and environmental conditions. The experiments were based on five varieties of spring barley (Basza, Blask, Skarb, Rubinek, Antek) sown in pure stands as well as in their mixtures. No fungicide and insecticides were used, only herbicide protection was implemented. Our studies have shown that in both locations the intensity of the disease was reduced in varieties grown in mixtures when compared to pure stands. This confirms that cultivation of genetically diversified varieties of spring barley in mixtures provides economically and environmentally sustainable tool which allows to control powdery mildew disease.
\end{abstract}

Keywords Spring barley $\cdot$ Variety mixtures $\cdot$ Powdery mildew $\cdot$ Disease reduction

\section{Introduction}

Powdery mildew is the most destructive disease of barley and is caused by the biotrophic fungus (Blumeria graminis f. sp. hordei) (Tratwal and Bocianowski 2014, Wolfe et al. 1997) that is of great economic importance in many barley production regions. In order to achieve sustainable use of pesticides, rules and guidelines for integrated pest control in Annex III "General principles of integrated pest management" to the Directive of the European Parliament and of the Council 2009/128/CE of 21 October 2009 established a framework for Community action which emphasize the use of all possible methods which reduce population of pests to the level of harmlessness. Section 4 of the annex points that "Sustainable biological, physical and other non-chemical

Anna Tratwal

A.Tratwal@iorpib.poznan.pl

1 Poland Department of Pests Methods Forecasting and Economy of Plant Control, Institute of Plant Protection National Research Institute Poznan, Władysława Wegorka 20, 60-318 Poznan, Poland

2 Department of Mathematical and Statistical Methods, Poznan University of Life Sciences, Wojska Polskiego 28, 60-637 Poznan, Poland methods must be preferred to chemical methods if they provide satisfactory pest control." Practical application of integrated pest control comprises of using alternative methods to chemical pest control. The general principle is to apply most effective and least harmful to the natural environment methods in a particular period of development of the cultivated plant. One of the relatively cheap and easy methods which increases the durability of genetic resistance of contemporary cultivars is their cultivation in different types of mixtures and in complex interbred populations according to the concept of evolutionary plant cultivation (Frison et al. 2001; Gacek 2000; Matyjaszczyk 2015; Newton et al. 2009, 2010). Mixed stands are less susceptible to unfavorable environmental conditions, such as weather fluctuations and other abiotic factors as well as more resistant to biotic stress (diseases, pests, weeds) (Finckh et al. 1998, 2000; Philips and Wolfe 2005; Wolfe 1990; Wolfe et al. 1997).

The aim of the research was to determine the influence of genetically diversified cultivar mixtures of spring barley on the development of epidemics of barley powdery mildew (B. graminis f. sp. hordei). For this we examined the level of infection of powdery mildew in variety mixtures of spring barley in field trials at two different locations in four growing seasons (2010-2013). 
Table 1 Characteristic features of spring barley cultivars used in the experiment (www.coboru.pl)

\begin{tabular}{llll}
\hline Variety & Cultivar type & \multicolumn{2}{l}{ Resistance to B. graminis } \\
\cline { 3 - 4 } & & Level $^{1}$ & Source of resistance \\
\hline Basza & Two-row, malting & 9.0 & mlo \\
Blask & Two-row, malting & 7.2 & Ly + un \\
Antek & Two-row, fodder & 6.1 & Ly + un \\
Skarb & Two-row, fodder & 7.2 & Mla + IM9 \\
Rubinek & Two-row, fodder & 8.3 & Mlo \\
\hline
\end{tabular}

${ }^{1}$ Resistance is expressed in a 9-grade scale, where 9 indicated full resistance, while 1 -full susceptibility

\section{Materials and methods}

\section{Field trials}

Field experiments with spring barley were carried out in four growing seasons: 2010, 2011, 2012 and 2013 at two locations: "Plant Breeding Smolice-IHAR Group Bakow Division, Opolskie $\left(50^{\circ} 42^{\prime} \mathrm{N}, 18^{\circ} 28^{\prime} \mathrm{E}\right)$ and Experimental
Station for Variety Station, Koscielna Wies, Wielkopolskie Province $\left(51^{\circ} 47^{\prime} \mathrm{N}, 18^{\circ} 00^{\prime} \mathrm{E}\right)$." The two sites differed in terms of soil and weather conditions. Five cultivars of spring barley, Basza, Blask, Antek, Skarb and Rubinek (Table 1), varying in resistance to barley powdery mildew were cultivated on plots of $10 \mathrm{~m}^{2}$ (Bakow) and $16.5 \mathrm{~m}^{2}$ (Koscielna Wies) in the split-plot system. The varieties were sown in pure stands and in all possible 10 two-way mixtures and 10 three-way mixtures combinations. The ratio of cultivar components in mixtures was $1: 1$ or 1:1:1. Rows spacing in plots is $12.5 \mathrm{~cm}$, seed drill type-Oyord (Bakow), SPZ 1,5/2 (Koscielna Wies). Fertilization-N: 60-60 kg/ha, P: 30-40 kg/ha, K: 50-60 kg/ha. Soil types: podzolic soil and leached brown soil (Bakow); leached brown soil; and acid brown soil (Koscielna Wies). No fungicide treatments were applied in the experiments.

\section{The assessment of resistance of barley to Blumeria graminis, powdery mildew}

Natural powdery mildew infections and pests on spring barley plants were assessed every 7-10 days during the
Table 2 Level of infection of powdery mildew (B. graminis $\mathrm{f}$. sp. hordei) (standard deviation) in varieties of spring barley in pure stands and in mixtures in growing season 2010

\begin{tabular}{|c|c|c|c|c|}
\hline \multirow[t]{2}{*}{ Combination } & \multicolumn{2}{|l|}{ AUDPC } & \multicolumn{2}{|l|}{ RAUDPC } \\
\hline & Bakow & Koscielna Wies & Bakow & Koscielna Wies \\
\hline Basza & $70.6(34.93)$ & $270.2(323.79)$ & & \\
\hline Blask & $185.7(48.04)$ & $277.4(248.24)$ & & \\
\hline Antek & $620.3(199.89)$ & 488.7 (374.28) & & \\
\hline Skarb & $262.2(53.36)$ & $272.3(268.1)$ & & \\
\hline Rubinek & $84.6(17.93)$ & $207.3(143.66)$ & & \\
\hline Basza/Blask & 74.1 (17.47) & $154.9(86.86)$ & 41.20 & 31.19 \\
\hline Antek/Basza & $198.2(35.65)$ & $192.5(105.86)$ & 40.97 & 9.06 \\
\hline Basza/Skarb & 74.1 (17.47) & $115.5(34.83)$ & 55.07 & 35.15 \\
\hline Basza/Rubinek & $77.5(22.11)$ & $135.3(92.53)$ & No reduction & 16.94 \\
\hline Antek/Blask & $244.4(79.46)$ & $246.8(87.63)$ & 36.19 & 6.91 \\
\hline Antek/Skarb & $346(75.09)$ & 290.7 (319.97) & 16.48 & 22.66 \\
\hline Antek/Rubinek & $220.8(67.73)$ & $218.6(78.45)$ & 36.13 & 25.07 \\
\hline Blask/Skarb & $141.8(5.82)$ & $85.3(0)$ & 34.43 & 59.38 \\
\hline Blask/Rubinek & $117.5(25.82)$ & 154.7 (98.69) & 11.06 & 9.10 \\
\hline Rubinek/Skarb & $142.9(52.99)$ & $110(49.36)$ & 17.93 & 43.01 \\
\hline Antek/Basza/Blask & 159.7 (37.99) & $211.5(87.15)$ & 43.35 & 10.01 \\
\hline Antek/Blask/Skarb & $200.6(46.08)$ & $130.6(30.17)$ & 41.62 & 62.28 \\
\hline Antek/Basza/Rubinek & $138.9(6.72)$ & $356.8(296.1)$ & 44.76 & No reduction \\
\hline Antek/Blask/Rubinek & $156.7(39.91)$ & $447.8(386)$ & 45.14 & No reduction \\
\hline Antek/Basza/Skarb & $114.1(29.08)$ & $207.6(69.81)$ & 64.04 & 18.78 \\
\hline Blask/Rubinek/Skarb & $103.6(36.24)$ & $369.5(212.42)$ & 42.83 & No reduction \\
\hline Basza/Blask/Rubinek & $85.1(35.06)$ & $288.2(101.11)$ & 26.88 & No reduction \\
\hline Antek/Rubinek/Skarb & $174(81.86)$ & $121(29.87)$ & 43.86 & 60.65 \\
\hline Basza/Blask/Skarb & $98.4(35.55)$ & $343.1(438.76)$ & 38.80 & No reduction \\
\hline Basza/Rubinek/Skarb & $95.5(35.77)$ & 177.4 (112.06) & 28.17 & 5.74 \\
\hline
\end{tabular}


Table 3 Level of infection of powdery mildew (B. graminis $\mathrm{f}$. sp. hordei) (standard deviation) in varieties of spring barley in pure stands and in mixtures in growing season 2011

\begin{tabular}{|c|c|c|c|c|}
\hline \multirow[t]{2}{*}{ Combination } & \multicolumn{2}{|l|}{ AUDPC } & \multicolumn{2}{|c|}{ RAUDPC } \\
\hline & Bakow & Koscielna Wies & Bakow & Koscielna Wies \\
\hline Basza & $38.8(0)$ & $37.2(0)$ & & \\
\hline Blask & $190.2(43.59)$ & $184(127.41)$ & & \\
\hline Antek & $514.5(90.6)$ & $367.3(84.08)$ & & \\
\hline Skarb & $224.9(76.87)$ & $172.6(60.17)$ & & \\
\hline Rubinek & $50.5(23.44)$ & $37.2(0)$ & & \\
\hline Basza/Blask & $94.8(34.47)$ & $85(9.41)$ & 14.51 & 4.42 \\
\hline Antek/Basza & $109.7(24.17)$ & $128.8(66.46)$ & 60.49 & 27.45 \\
\hline Basza/Skarb & $83.1(32.45)$ & $86(34.97)$ & 28.24 & 10.88 \\
\hline Basza/Rubinek & $42.3(6.98)$ & $68.1(29.27)$ & 3.81 & No reduction \\
\hline Antek/Blask & $233.6(28.3)$ & $205.5(22.17)$ & 33.58 & 20.28 \\
\hline Antek/Skarb & 286.5 (89.9) & $323.3(214.73)$ & 20.62 & No reduction \\
\hline Antek/Rubinek & $182.2(81.68)$ & $163.8(90.54)$ & 34.41 & 12.94 \\
\hline Blask/Skarb & $181.3(34.28)$ & $95.9(18.13)$ & 6.19 & 42.12 \\
\hline Blask/Rubinek & $71.4(30.1)$ & $108(81.3)$ & 35.54 & 7.38 \\
\hline Rubinek/Skarb & $130.6(47.83)$ & $95.9(18.13)$ & 3.45 & No reduction \\
\hline Antek/Basza/Blask & $138.8(42.68)$ & $168.5(66.78)$ & 43.32 & 6.45 \\
\hline Antek/Blask/Skarb & $212.5(25.7)$ & $205.5(22.17)$ & 31.05 & 12.33 \\
\hline Antek/Basza/Rubinek & $123(55.15)$ & $152.8(89.61)$ & 40.83 & No reduction \\
\hline Antek/Blask/Rubinek & $190.2(43.59)$ & $109.6(21.86)$ & 23.42 & 42.05 \\
\hline Antek/Basza/Skarb & $169.5(79.05)$ & $109.6(13.41)$ & 36.12 & 42.85 \\
\hline Blask/Rubinek/Skarb & $117.9(24.02)$ & $95.9(18.13)$ & 22.19 & 17.68 \\
\hline Basza/Blask/Rubinek & $89.4(8.73)$ & $94.6(25.8)$ & 1.85 & No reduction \\
\hline Antek/Rubinek/Skarb & $173.8(70.95)$ & $146.6(47.26)$ & 31.17 & 23.03 \\
\hline Basza/Blask/Skarb & $143.9(63.25)$ & $173.4(95.63)$ & 2.51 & No reduction \\
\hline Basza/Rubinek/Skarb & $83.1(37.52)$ & 88.9 (23.99) & 16.71 & No reduction \\
\hline
\end{tabular}

growing season (on mature plants?). The intensity of the disease infection was assessed using the following 9-grade scale where " 1 " indicated full susceptibility, while "9" full resistance (no symptoms of the disease) (Kaczynski et al. 1998). The obtained results were expressed as a percentage value of damage caused by the disease to particular plants of pure cultivars and mixtures. Analyses were carried out on individually converted percentage value.

\section{The area under disease progress curve}

The area under disease progress curve (AUDPC) value was calculated according to the following formula (Tratwal and Bocianowski 2014)

$\mathrm{AUDPC}=\sum_{i=1}^{n}\left\{\left(\frac{y_{i}+y_{i-1}}{2}\right)\left(x_{i}-x_{i-1}\right)\right\}$,

where AUDPC is the area under disease progress curve, $y_{i}$ is the percentage of visible infected area $\left(y_{i} / 100\right)$ at the $i$-th observation, $x_{i}$ is the day of the $i$-th observation, and $n$ indicates the total number of observations (modified from Shaner and Finney 1977).
The relative area under disease progress curve (RAUDPC) for mixtures was calculated by comparing the area under disease for mixtures with the area under disease for cultivars in pure stands (mixture components).

\section{The assessment of yield}

Mature grain was harvested from each plot using combine. Weight of grain from each plot was measured and used to calculate yield in dt/ha. Yield from mixtures was calculated as an expected yield. The expected yield is a comparison between average yield from pure stands (mixture components) and yield from mixture.

\section{Statistical analysis}

The normality of distribution of the studied traits was tested using the Shapiro-Wilk's normality test (Shapiro and Wilk 1965). Three-way analysis of variance (ANOVA) was performed to verify the hypotheses of lack of effects of locations, years and cultivars, cultivars/mixtures and the hypotheses about a lack of all interactions on the variability 
Table 4 Level of infection of powdery mildew (B. graminis $\mathrm{f}$. sp. hordei) (standard deviation) on cultivars of spring barley in pure stands and in mixtures in the 2012 season

\begin{tabular}{|c|c|c|c|c|}
\hline \multirow[t]{2}{*}{ Combination } & \multicolumn{2}{|l|}{ AUDPC } & \multicolumn{2}{|l|}{ RAUDPC } \\
\hline & Bakow & Koscielna Wies & Bakow & Koscielna Wies \\
\hline Basza & $57.7(19.2)$ & $31.9(15.42)$ & & \\
\hline Blask & $123.5(44.81)$ & $94.5(97.41)$ & & \\
\hline Antek & $781.3(13.71)$ & $162.4(81.55)$ & & \\
\hline Skarb & $168.8(16.45)$ & 56.5 (38.69) & & \\
\hline Rubinek & $99.5(54.73)$ & $23.8(4.07)$ & & \\
\hline Basza/Blask & $86.5(0)$ & $38(14.87)$ & 1.15 & 10.38 \\
\hline Antek/Basza & $195.8(78.47)$ & $89.4(52.63)$ & 53.75 & 23.36 \\
\hline Basza/Skarb & $109.1(45.25)$ & $38(18.81)$ & 3.98 & 12.18 \\
\hline Basza/Rubinek & $57.7(19.2)$ & $57.1(11.61)$ & 24.01 & No reduction \\
\hline Antek/Blask & $319.1(126.89)$ & $55.8(24.43)$ & 29.68 & 47.39 \\
\hline Antek/Skarb & $365.5(70.41)$ & $46.9(21.15)$ & 23.04 & 63.19 \\
\hline Antek/Rubinek & $221.3(66.86)$ & $44.9(23.59)$ & 49.37 & 59.04 \\
\hline Blask/Skarb & $114.1(42.98)$ & $29.9(16.29)$ & 19.17 & 25.11 \\
\hline Blask/Rubinek & $86.5(0)$ & $33.9(14.11)$ & 12.98 & 16.46 \\
\hline Rubinek/Skarb & $123.5(44.81)$ & $42.1(14.11)$ & 0.81 & 9.29 \\
\hline Antek/Basza/Blask & $154.5(38.04)$ & $59.1(9.6)$ & 51.64 & 44.67 \\
\hline Antek/Blask/Skarb & $224.8(83.65)$ & $33.9(8.14)$ & 37.42 & 59.22 \\
\hline Antek/Basza/Rubinek & $174.5(74.48)$ & $53(17.88)$ & 43.94 & 41.30 \\
\hline Antek/Blask/Rubinek & $149(47.39)$ & $46.9(11.61)$ & 54.64 & 48.69 \\
\hline Antek/Basza/Skarb & $179.8(26)$ & $33.9(14.11)$ & 46.50 & 64.87 \\
\hline Blask/Rubinek/Skarb & $120(49)$ & $33.9(14.11)$ & No reduction & 17.56 \\
\hline Basza/Blask/Rubinek & $86.5(0)$ & $44.9(15.61)$ & 1.10 & No reduction \\
\hline Antek/Rubinek/Skarb & $271.4(50.02)$ & $52.3(4.07)$ & 21.75 & 43.01 \\
\hline Basza/Blask/Skarb & $86.5(0)$ & $33.8(15.53)$ & 25.01 & 27.48 \\
\hline Basza/Rubinek/Skarb & $52.8(0)$ & $66.3(25.53)$ & 50.50 & No reduction \\
\hline
\end{tabular}

of level of infection of powdery mildew and grain yield. Mean values, standard deviations and least significant differences (LSDs) were calculated which permitted creation of homogeneous groups for level of infection of powdery mildew and grain yield. Contrast analysis was performed to test the difference in powdery mildew resistance between cultivars and their mixtures, between mixtures and single cultivars, as well as between three-way and two-way mixtures. Data analysis was performed using GenStat 17 th edition.

\section{Results}

In order to test the influence of genetically diversified cultivar mixtures of spring barley on the development of epidemics of barley powdery mildew, five cultivars of spring barley varying in resistance to barley powdery mildew were cultivated (Table 1) at two locations. The studies were carried out in four consecutive years from 2010 to 2013. The most prevalent among other observed disease was powdery mildew; other diseases such as leaf rust (Puccinia hordei) or scald were observed at much smaller intensity, at the trace level (data not shown).

The analysis of variance indicated that AUDPC was not influenced by the location $\left(F_{1600}=1.06, p=0.573\right)$ or the interaction of location $\times$ cultivar/mixture $\left(F_{24,600}=1.07\right.$, $p=0.501)$. There was statistically significant influence of years $\quad\left(F_{3600}=47.43, \quad p<0.001\right), \quad$ cultivars/mixtures $\left(F_{24,600}=31.01, \quad p<0.001\right), \quad$ the interaction of years $\times$ cultivars/mixtures $\left(F_{72,600}=2.50, p<0.001\right)$, as well as interaction of location $\times$ years $\times$ cultivars $/$ mixtures $\left(F_{72,600}=2.12, p<0.001\right)$.

Average AUDPC for varieties in pure stands also varied in all four growing seasons. In Bakow average AUDPC in pure stands ranged from 203.79 (2011) to 283.23 in growing season 2013. The biggest differences in AUDPC were observed for varieties in growing season 2011 and ranged from 57.71 (Basza) to 781.34 (Antek) (Table 2).

In Koscielna Wies AUDPC in pure stands ranged from 73.83 (2012) to 412.54 in growing season 2013. The biggest differences in AUDPC were recorded for the year 
Table 5 Level of infection of powdery mildew (B. graminis $\mathrm{f}$. sp. hordei) (standard deviation) on cultivars of spring barley in pure stands and in mixtures in the 2013 season

\begin{tabular}{|c|c|c|c|c|}
\hline \multirow[t]{2}{*}{ Kombinacja } & \multicolumn{2}{|l|}{ AUDPC } & \multicolumn{2}{|c|}{ RAUDPC } \\
\hline & Bakow & Koscielna Wies & Bakow & Koscielna Wies \\
\hline Basza & $66.3(0)$ & $71(15.94)$ & & \\
\hline Blask & 251.4 (39) & $361.5(233.57)$ & & \\
\hline Antek & 770.8 (197.56) & $1209.2(428.7)$ & & \\
\hline Skarb & $272.3(49.1)$ & $313.6(264.56)$ & & \\
\hline Rubinek & $55.3(17.45)$ & $107.4(69.61)$ & & \\
\hline Basza/Blask & $132.3(28.57)$ & $78.4(20.64)$ & 15.52 & 51.99 \\
\hline Antek/Basza & $238.2(115.51)$ & $500.9(392.25)$ & 45.66 & 11.82 \\
\hline Basza/Skarb & $89.3(26.8)$ & $194.9(257.01)$ & 44.27 & No reduction \\
\hline Basza/Rubinek & $56.4(11.42)$ & $107.8(68.87)$ & 6.94 & No reduction \\
\hline Antek/Blask & $310.4(162.82)$ & $446.5(272.28)$ & 32.10 & 34.92 \\
\hline Antek/Skarb & 334.9 (134.93) & 747.8 (267.64) & 31.46 & No reduction \\
\hline Antek/Rubinek & $229.8(57.17)$ & $292.6(274.44)$ & 44.49 & 47.23 \\
\hline Blask/Skarb & $144.8(38.84)$ & $155.2(37.33)$ & 43.84 & 38.31 \\
\hline Blask/Rubinek & $103.9(16.55)$ & $244.1(140.84)$ & 29.91 & No reduction \\
\hline Rubinek/Skarb & $76.5(9.89)$ & $198.8(170.77)$ & 51.51 & No reduction \\
\hline Antek/Basza/Blask & $177(79.02)$ & $246.2(148.21)$ & 51.93 & 47.64 \\
\hline Antek/Blask/Skarb & $160.4(74.91)$ & $294.9(87.6)$ & 63.39 & 46.84 \\
\hline Antek/Basza/Rubinek & $160.3(60.79)$ & $216.3(118.34)$ & 39.86 & 52.83 \\
\hline Antek/Blask/Rubinek & $227.1(38.84)$ & $321.3(172.83)$ & 34.53 & 37.31 \\
\hline Antek/Basza/Skarb & $188.9(86.37)$ & 233.7 (118.34) & 47.54 & 57.14 \\
\hline Blask/Rubinek/Skarb & $137.3(62.33)$ & $144.1(97.27)$ & 29.00 & 15.20 \\
\hline Basza/Blask/Rubinek & $111.9(59.55)$ & $107.8(70.94)$ & 10.75 & 7.16 \\
\hline Antek/Rubinek/Skarb & $165.4(81.38)$ & $452.6(246.72)$ & 55.90 & 3.16 \\
\hline Basza/Blask/Skarb & $98.9(20.15)$ & $95.1(28.71)$ & 49.54 & 46.19 \\
\hline Basza/Rubinek/Skarb & $82.6(14.31)$ & $117.8(75.45)$ & 35.97 & 25.14 \\
\hline
\end{tabular}

Table 6 Assessment of differences between cultivars and their mixtures for the AUDPC value

\begin{tabular}{|c|c|c|c|c|c|c|c|c|}
\hline Contrast & $\begin{array}{l}\text { Bakow } \\
2010\end{array}$ & $\begin{array}{l}\text { Bakow } \\
2011\end{array}$ & $\begin{array}{l}\text { Bakow } \\
2012\end{array}$ & $\begin{array}{l}\text { Bakow } \\
2013\end{array}$ & $\begin{array}{l}\text { Koscielna } \\
\text { Wies } 2010\end{array}$ & $\begin{array}{l}\text { Koscielna } \\
\text { Wies } 2011\end{array}$ & $\begin{array}{l}\text { Koscielna } \\
\text { Wies } 2012\end{array}$ & $\begin{array}{l}\text { Koscielna } \\
\text { Wies } 2013\end{array}$ \\
\hline Basza-Basza in mixtures & -41 & $-69 *$ & $-61^{*}$ & -67 & 52 & $-78^{*}$ & -19 & -119 \\
\hline Blask-Blask in mixtures & 47 & 43 & -19 & $91^{*}$ & 34 & 50 & $54 * *$ & 148 \\
\hline Antek-Antek in mixtures & $425 * * *$ & $333^{* * *}$ & $556 * * *$ & $552 * * *$ & $246^{*}$ & $196 * * *$ & $111^{* * *}$ & $834 * * *$ \\
\hline Skarb-Skarb in mixture & $113 * * *$ & $67^{*}$ & 4 & $124 * *$ & 77 & 31 & 15 & 50 \\
\hline $\begin{array}{l}\text { Rubinek-Rubinek in } \\
\text { mixtures }\end{array}$ & -47 & $-70^{*}$ & -35 & -80 & -31 & $-75^{*}$ & -24 & -113 \\
\hline $\begin{array}{l}\text { Varieties_-varieties in all } \\
\text { mixtures }\end{array}$ & $96 * * *$ & $61 * * *$ & $87 * * *$ & $122 * * *$ & 85 & 24 & $27.1 * *$ & $153 * *$ \\
\hline $\begin{array}{l}\text { Varieties-varieties in } 2 \\
\text { components }\end{array}$ & $81 * * *$ & $62 * * *$ & $78 * * *$ & $112 * * *$ & $133^{*}$ & 24 & $26.2 * *$ & $116^{*}$ \\
\hline $\begin{array}{l}\text { Varieties-varieties in } 3 \\
\text { components }\end{array}$ & $112 * * *$ & $60 * * *$ & $96 * * *$ & $132 * * *$ & 38 & 25 & $28 * *$ & $190 * * *$ \\
\hline $\begin{array}{l}\text { Two-row mixtures-three- } \\
\text { row mixtures }\end{array}$ & $31 *$ & -3 & 18 & 21 & $-95^{*}$ & 1 & 1.8 & 74 \\
\hline
\end{tabular}

$* p<0.05 ; * * p<0.01 ; * * * p<0.001$ 
Table 7 Results of threefactorial variance analysis

\begin{tabular}{lrcrrr}
\hline Source of variation & $d f$ & Sum of squares & Mean square & $F$ statistic & $F$ pr. \\
\hline Object & 24 & 4569.49 & 190.4 & 8.99 & $<.001$ \\
Place & 1 & $15,566.61$ & $15,566.61$ & 735.27 & $<.001$ \\
Year & 3 & $28,267.27$ & 9422.42 & 445.06 & $<.001$ \\
Object $\times$ place & 24 & 233.34 & 9.72 & 0.46 & 0.988 \\
Object $\times$ year & 72 & 2979.45 & 41.38 & 1.95 & $<.001$ \\
Place $\times$ year & 3 & 6844.29 & 2281.43 & 107.76 & $<.001$ \\
Object $\times$ place $\times$ year & 72 & 2500.94 & 34.74 & 1.64 & 0.001 \\
Residual & 600 & $12,702.81$ & 21.17 & & \\
Total & 799 & $73,664.2$ & & &
\end{tabular}

2013, including cultivars Basza and Antek. They ranged from 71.05 to 1209.19 (Tables 2, 3, 4, 5).

In all three growing seasons, at both sites Antek was the most susceptible to powdery mildew in pure stands when compared to other tested cultivars (Tables 2, 3, 4, 5). In growing season 2010 similar level of powdery mildew infection was observed at both locations. Basza was more susceptible to powdery mildew in Koscielna Wies than in Bakow. The intensity of infections was reduced in variety mixtures to the level of $11.06-64.04 \%$ for Bakow (excluding Basza/Rubinek combination) and 5.74-62.28\% for Koscielna Wies (excluding Antek/Basza/Rubinek, Antek/ Blask/Rubinek, Blask/Rubinek/Skarb, Basza/Blask/Rubinek, Basza/Blask/Skarb combinations) when compared to pure stands (Table 2).

In the 2011, bigger differences in the level of disease infection were recorded only for the Antek and the intensity of disease symptoms was much higher in Bakow than in Koscielna Wies (Table 3).

At both sites, the level of powdery mildew infection in mixtures was reduced to the levels of $1.85-60.49 \%$ for Bakow and 4.42-42.85\% for Koscielna Wies (excluding combinations: Basza/Rubinek, Antek/Skarb, Rubinek/ Skarb, Antek/Basza/Rubinek, Basza/Blask/Rubinek Basza/ Blask/Skarb, Basza/Rubinek/Skarb), when compared to pure stands (Table 3 ).

In growing season 2012 the intensity of powdery mildew infection in Koscielna Wies was much higher on all tested cultivars in pure stands when compared to the previous 2011 season. At the same growing season in Bakow higher level of infection in pure stands was only observed on Basza and Antek (Table 4).

For both locations, the disease infection was reduced in mixture to the levels of $0.81 \%$ to $54.64 \%$ for Bakow (excluding Blask/Rubinek/Skarb combination) and 9.29-64.87\% (for Koscielna Wies, excluding combinations: Basza/Rubinek, Basza/Blask/Rubinek and Basza/ Rubinek/Skarb) when compared with pure stands (Table 4).
In Koscielna Wies, higher level of infection of powdery mildew was observed on the varieties in pure stands in growing season 2013 when compared to the season 2012. In Bakow, higher level of infection was observed on four cultivars excluding Rubinek in 2013 when compared to growing season 2012 (Table 5).

For both locations, the disease infection was much lower and reduced in mixtures when compared to pure stands to the level of $6.94 \%$ (Basza/Rubinek) to $63.39 \%$ (Antek/ Blask/Skarb) in Bakow and 3.16-57.14\% in Koscielna Wies (except combinations of Basza/Skarb, Basza/Rubinek, Antek/Skarb, Blask/Rubinek i Rubinek/Skarb) (Table 5).

The difference between the cultivars and their mixtures in terms of the AUDPC value in particular locations and years was expressed as relevant contrast values (Table 6). The AUDPC values were significantly higher in pure stands when compared with mixtures and were observed in Antek at both sites and all three growing seasons. Mixtures with the Basza showed significantly bigger AUDPC values than the pure stand in 2011 growing season in both locations and in 2012 in Bakow. On average, single cultivars showed bigger AUDPC values than the two-way, threeway and all mixtures together in Bakow in all three growing seasons. In Koscielna Wies, such correlation was observed in 2012 and 2013 (Table 6).

The results of analysis of variance indicated that grain yield was influenced by the cultivar/mixture $\left(F_{24,600}=8.99, \quad p<0.001\right)$, location $\left(F_{1600}=735.27\right.$, $p<0.001)$, year $\left(F_{3600}=445.06, p<0.001\right)$, the interaction of cultivar/mixture $\times$ year $\quad\left(F_{72,600}=1.95\right.$, $p<0.001)$, location $\times$ year interaction $\left(F_{3600}=107.76\right.$, $p<0.001)$ and cultivar/mixture $\times$ location $\times$ year interaction $\left(F_{72,600}=1.64, p=0.001\right)($ Table 7$)$.

In Bakow, grain yield (dt/ha) of varieties in pure stands ranged from 45.78 (Antek) to 63.68 (Skarb) in season 2010; 35.38 (Blask) to 40.88 (Rubinek) in 2011; 53.55 (Antek) to 65.98 (Blask) in 2012; and 31.73 (Antek) to 51.55 (Basza) in 2013. 


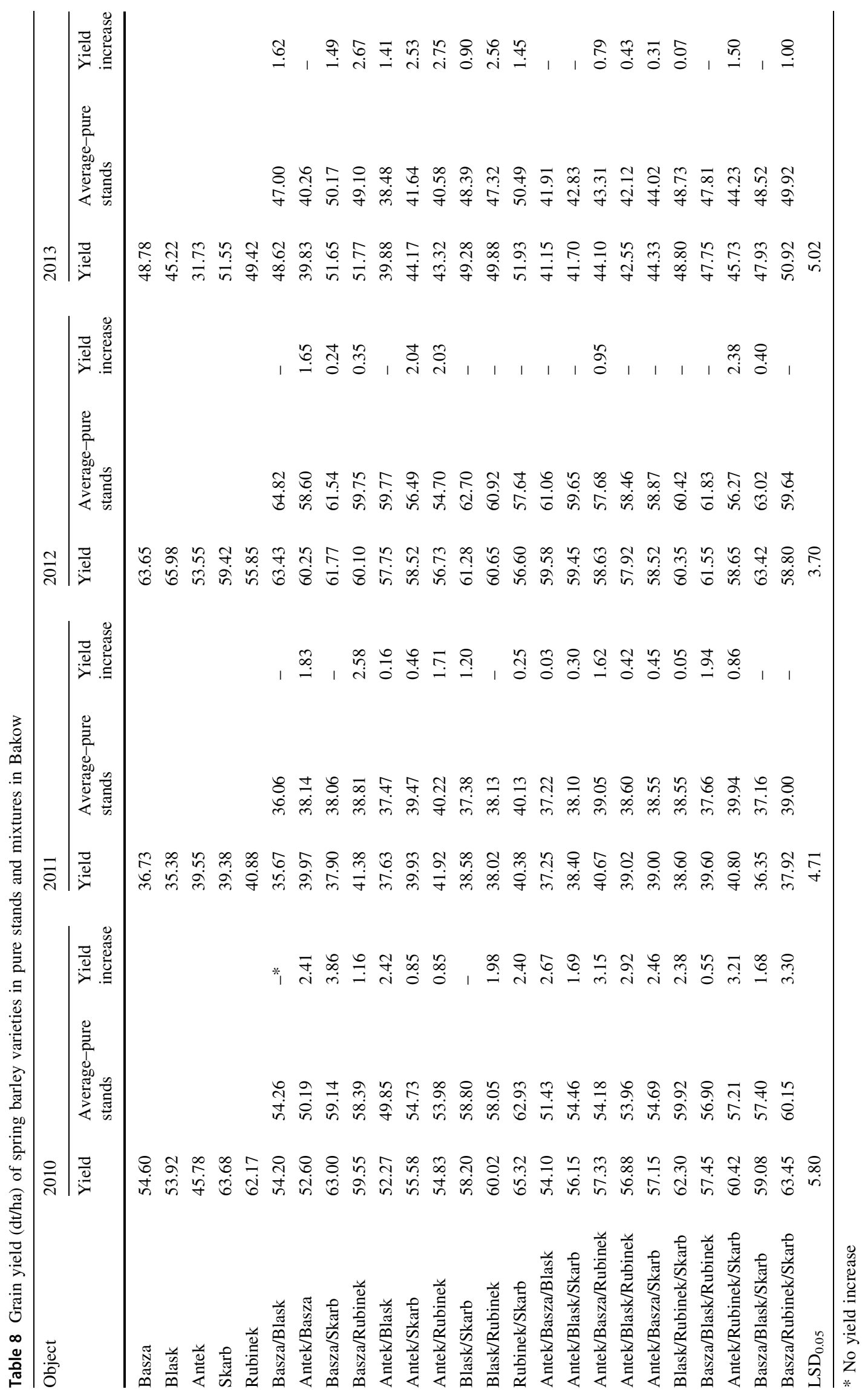




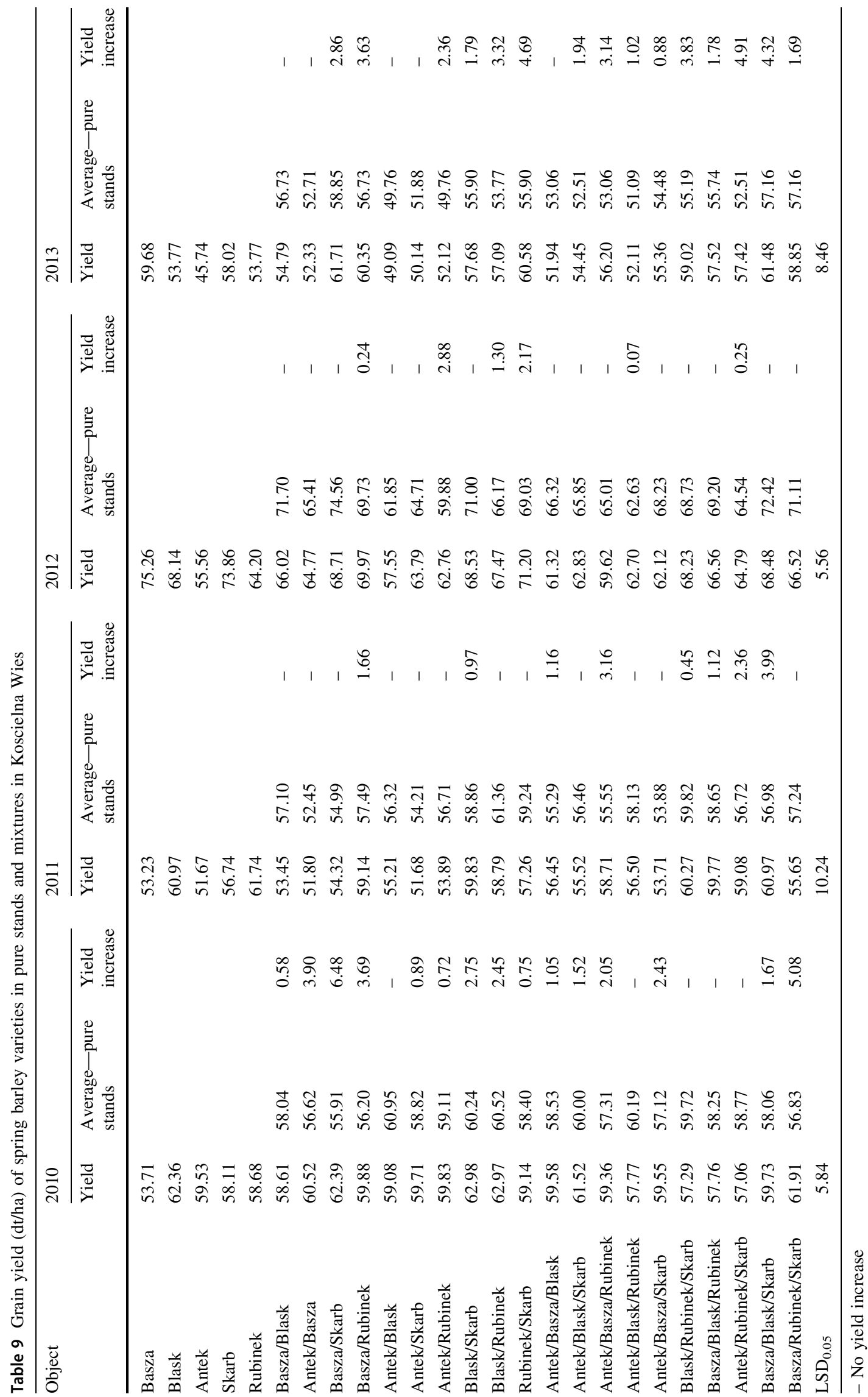


Variety mixtures yielded (dt/ha) 52.27 (Antek/Blask) to 65.32 (Rubinek/Skarb) in season 2010; 35.67 (Basza/ Blask) to 41.92 (Antek/Rubinek) in 2011; 56.60 (Rubinek/ Skarb) to 63.43 (Basza/Blask) in 2012; 39.83 (Antek/ Basza) to 51.93 (Rubinek/Skarb) in 2013.

The growth of yield in mixtures when compared to pure stands (dt/ha) ranged from 0,55 (Basza/Blask/Rubinek) to 3.86 (Basza/Skarb) in 2010; 0.03 (Antek/Basza/Blask) to 2.58 (Basza/Rubinek) in 2011; 0.24 (Basza/Skarb) to 2.38 (Antek/Rubinek/Skarb) in 2012; and 0.07 (Blask/Rubinek/ Skarb) to 2.75 (Antek/Rubinek) in 2013 (Table 8).

In Koscielna Wies grain yield (dt/ha) of varieties in pure stands ranged from 5371 (Basza) to 62.36 (Blask) in 2010; 51.57 (Antek) to 61.47 (Rubinek) in 2011; 55.56 (Antek) to 75.26 (Basza) in 2012; 45.74 (Antek) to 59.68 (Basza) in 2013.

Variety mixtures yielded (dt/ha) 57.06 (Antek/Rubinek/ Skarb) to 60.52 (Blask/Rubinek) in 2010; 51.68 (Antek/ Skarb) to 60.97 (Basza/Blask/Skarb) in 2011; 57.55 (Antek/Blask) to 71.20 (Rubinek/Skarb) in 2012; 49.09 (Antek/ Blask) to 61.71 (Basza/Skarb) in 2013.

Yield growth in mixtures when compared to pure stands (dt/ha) ranged from 0.58 (Basza/Blask) to 6.48 (Basza/ Skarb) in 2010; 0.45 (Blask/Rubinek/Skarb) to 3.99 (Basza/Blask/Skarb) in 2011; 0.07 (Antek/Blask/Rubinek) to 2.88 (Antek/Rubinek) in 2012; 0.88 (Antek/Basza/ Skarb) to 4.69 (Rubinek/Skarb) in 2013 (Table 9).

\section{Discussion}

It has been shown that the intensification of the disease caused by monoculture could be avoided by retaining diversity within the cereal crops (Finckh et al. 2000; Newton et al. 2009). Our study has shown that cultivation of varieties of spring barley in mixtures reduces the intensity of powdery mildew disease when compared to pure stands.

Modern plant protection methods have to be compliant with the ideas of sustainable agriculture, whose premise is plant protection that is economically profitable, environmentally friendly and accepted in the community. In light of that, contemporary systems of cultivated plant protection should incorporate any available methods of pest control. Those include both interspecies mixtures and intercultivar mixtures within the same species. In recent years, in Poland about $17 \%$ of general growing area has been sown with mixtures (cereal and cereal-leguminous).

The biggest advantage of cultivating crops in mixtures is introducing biodiversity and individual features of particular plants which allows a better use of the environmental resources without disturbing its biological balance. Genetic diversity in mixed stands is increased when compared to pure stands. Main advantages of cultivating crops in variety mixtures involve an increased genetic distance between plants with the same genetic resistance to diseases, restriction of pathogen spread by resistant plants which form a natural barrier, competitive interactions among host plants affecting their disease susceptibility (Finckh et al. 2000).

Relationship between disease severity and mixtures composition was found in the experiments involving different sets of mixtures of four near-isogenic barley lines. The powdery mildew levels in the mixtures were reduced most when the mean resistance of pure stands was intermediate (Kolster et al. 1989). Other researchers (Gacek 2000; Tratwal et al. 2007; Tratwal and Walczak 2010) also observed a reduction in the level of powdery mildew infection in mixtures of spring cereal when compared to pure stands of up to $75 \%$. The Directive of the European Parliament and of the Council 2009/128/CE of 21 October 2009 established a framework for Community action which emphasize the use of all possible sustainable methods which reduce the use of pesticides. Together, our study confirms that cultivation of spring barley varieties in mixtures might be used in both industrialized and organic agriculture which is of great economic importance as integrated plant protection requires the use of non-chemical methods (biological, physical) against pathogens.

\section{Conclusions}

1. Powdery mildew (B. graminis f. sp. hordei) was the most prevalent among other observed diseases, and Antek cultivar was the most susceptible to powdery mildew in each trial (year and location).

2. Our study has shown that there was a positive effect of cultivating mixtures of spring barley varieties in terms of their resistance to powdery mildew (B. graminis $\mathrm{f}$. sp. hordei) and yield increase.

3. Cultivation of spring barley as a variety mixture is an alternative way of growing this crop instead of monoculture (single variety) in low cost and ecological farming.

4. Further work is required to develop mixtures of spring barley on a wider scale, especially selecting new varieties for mixtures development.

\section{Compliance with ethical standards}

Conflict of interest All authors declare that they have no conflict of interest. 
Open Access This article is distributed under the terms of the Creative Commons Attribution 4.0 International License (http://creative commons.org/licenses/by/4.0/), which permits unrestricted use, distribution, and reproduction in any medium, provided you give appropriate credit to the original author(s) and the source, provide a link to the Creative Commons license, and indicate if changes were made.

\section{References}

Finckh MR, Gacek ES, Czembor HJ, Wolfe MS (1998) Host frequency and density effects on disease and field in mixtures of barley. Plant Pathol 48:807-816

Finckh MR, Gacek ES, Goyeau H, Lannou Ch, Merz U, Mundt CC, Munk L, Nadziak J, Newton AC, de Vallavieille-Poppe C, Wolfe MS (2000) Cereal variety and species mixtures in practice, with emphasis on disease resistance. Agronomie 20:813-837

Frison EA, Cherfas J, Hodgin T (2001) Agricultural biodiversity is essential for sustainable improvement in food and nutrition security. Sustainability 3:238-253

Gacek E (2000) Wykorzystanie różnorodności genetycznej roślin w zwalczaniu chorób roślin uprawnych. [Utilization of genetical diversity to control the diseases of cultivated plants]. Post. Nauk Rol. 5:17-25

Kaczyński L., Zych J., Behnke M., Lewandowska B., Szymczyk R. (1998). Metodyka badania wartości gospodarczej odmian (WGO) roślin uprawnych. Methodology for VCU tests of agricultural plants 1 . Rośliny rolnicze 1.1. Zbożowe. COBORU, Wydanie 1, Słupia Wlk.

Kolster RC, Munk L, Stolen O (1989) Disease severity and grain yield in barley multilines with resistance to powdery mildew. Crop Sci 29:1459-1463
Matyjaszczyk E (2015) Prevention methods for pest control and their use in Poland. Pest Manag Sci 71(4):485-491

Newton AC, Begg GS, Swanston JS (2009) Deployment of diversity for enhanced crop function. Ann Appl Biol 154(3):309-322 (ISSN 0003-4746)

Newton AC, Gravouil C, Fountaine JM (2010) Managing the ecology of foliar pathogens: ecological tolerance in crops. Ann Appl Biol 157:343-359

Philips SL, Wolfe MS (2005) Evolutionary plant breeding for low input systems. J Agric Sci 143(4):245-254

Shaner G, Finney RE (1977) The effect of nitrogen fertilization on the expression of slow-mildewing resistance in Knox wheat. Phytopathology 67(12):1833-1837

Shapiro SS, Wilk MB (1965) An analysis of variance test for normality (complete samples). Biometrika 52:591-611

Tratwal A, Bocianowski J (2014) Blumeria graminis f. sp. hordei virulence frequency and the powdery mildew incidence on spring barley in the Wielkopolska province. J Plant Prot Res 54(1):28-35

Tratwal A, Walczak F (2010) Powdery mildew (Blumeria graminis) and pest occurrence reduction in spring cereals mixtures. J Plant Prot Res 50(3):372-377

Tratwal A, Law J, Philpott H, Horwell A, Garner J (2007) The possibilities of reduction of winter barley chemical protection by growing variety mixtures. Part I. Effect on powdery mildew level. J Plant Prot Res 47(1):65-77

Wolfe MS (1990) Intra-crop diversification: disease, yield and quality. Monograph-Br Crop Prot Counc 45:105-114

Wolfe MS, Lannou C, Pope C, Finckh MR, Munk L, Merz U, Valenghi D, Gacek E (1997) Variety mixtures in theory and practice. Cost Action 817. Compiled by Working Group 2. INRA-Grignon-France, May 1997 